\title{
A 40 años del Golpe en Chile
}

El golpe de estado de 1973, las violaciones de derechos humanos, el exilio, los legados institucionales y el modelo económico impulsados por la dictadura de Augusto Pinochet y sus colaboradores civiles y militares no son temas del pasado; están muy presentes tanto en la vida social y política de los chilenos como en distintos ámbitos de la comunidad internacional. Esta es tal vez la más notoria conclusión en que convergen los seis artículos que conforman el presente número de Revista Política.

Fruto de un esfuerzo editorial conjunto del Instituto de Asuntos Públicos de la Universidad de Chile y la Asociación Chilena de Ciencia Política, este número temático ofrece una reflexión en torno al $40^{\circ}$ aniversario del golpe en Chile que, lejos de constituir una mera rememoración de hechos del pasado, da cuenta del poder explicativo que tienen los mismos para analizar la vida política actual. La diversidad de los enfoques incluidos permite abordar distintos aspectos de esta reflexión: la divergente evolución que han tenido las dimensiones política y económica del golpe; el impacto que produjo en distintos públicos fuera del país y, al mismo tiempo, la forma como esos públicos influyeron en la política nacional; la función clave de Chile en la construcción de regímenes internacionales de derechos humanos; la acción de la autoridad política vis-à-vis la sociedad civil en los modestos avances en materia de justicia transicional, y el rol político, testimonial y pedagógico de la memoria en la construcción de una sociedad democrática.

Los artículos aquí reunidos dan cuenta de la imponente vigencia del golpe y sus consecuencias como explicación a fenómenos actuales de la sociedad chilena. No se trata de querer "abrir heridas del pasado", sino comprender mejor el Chile actual. La evolución política que ha vivido el país durante 
los últimos años -especialmente las masivas movilizaciones de cientos de miles de chilenos- dan muestra de que el pasado está muy lejano de la conciencia de los jóvenes, y al mismo tiempo, es una dimensión fundamental para comprender aquellas cosas que hoy se rechazan (y, probablemente, también las que aprueban).

Al fenómeno reciente de películas y series de época en televisión se sumaron por primera vez masivas audiencias interesadas en acceder, a través de la pantalla, a versiones documentales o de ficción de las violaciones a los derechos humanos. La centro-izquierda se vuelve más crítica de la transición; sectores de la derecha intentan deprenderse de la carga moral de haber apoyado a la dictadura. Al mismo tiempo, las encuestas muestran que el crecimiento económico no va, necesariamente, de la mano con el fortalecimiento de la democracia. Chile enfrenta una sociedad fragmentada y que desconfia de las instituciones.

Estamos culminando un año de intensa activación de la memoria y de una reelaboración social de los legados del golpe y la dictadura, pero no es posible entender estos fenómenos sin considerar los hechos que desencadenó el 11 de septiembre de 1973. Esperamos que este número temático sea un aporte a esta necesaria reflexión.

Claudia Heiss - Presidenta Asociación Chilena de Ciencia Política

Robert Funk - Editor Revista Política 